Silvia Calpena Martínez Irene Carrillo Acosta Beatriz Álvarez Álvarez Miguel Górgolas Hernández-Mora

\section{A case report. Rediscovering tuberculostatics drugs: skin rash and pyrazinamide}

Infectious Diseases Department, Fundación Jiménez Díaz, Universidad Autónoma de Madrid.

Article history

Received: 9 November 2021; Revision Requested: 23 December 2021; Revision Received: 23 December 2021; Accepted: 15 January 2022; Published: 1 March 2022

\section{Sir,}

Since the use of anti-tuberculosis drugs began in 1950s, the most well-known adverse reactions to anti-tuberculosis treatment are gastrointestinal, which can lead to therapeutic non-compliance. In addition, it is known that there may be mild skin lesions, such as acne or rash, generally during the first trimester [1].

A 50-year-old male patient, native of Morocco and with habitual residence in Spain for the last 20 years, without a personal history of interest, presented with a constitutional syndrome with weight loss of 4 kilograms and intermittent fever of 2 months of evolution, accompanied by hyporexia, asthenia and predominantly nocturnal sweating. He made annual trips to Morocco and did not remember contact with animals or people sick with tuberculosis (TB).

On physical examination, he had no pathological lymphadenopathy, skin lesions, or palpable organomegaly. Serum biochemistry was normal and tumor markers were negative (CEA, CA125, Ca15-3, Ca19.9, FP, HCG). The serologies were negative for hepatotropic viruses and HIV. A thoraco-abdomen-pelvic computed tomography (CT) was performed, showing a soft tissue mass located in the posterior mediastinum at the level of D4 to D9, a $5 \times 5 \times 11 \mathrm{~cm}$ lesion, of homogeneous density, encompassing the thoracic aorta descending from the aortic arch until entering the abdominal cavity. It showed mediastinal lymphadenopathies of up to $20 \mathrm{~mm}$ and an anterior paraspinal mass, with irregular edges that surrounded the common iliac arteries, extending through the retroperitoneum in contact with the ureters more pronounced on the right, findings suggestive of retroperitoneal fibrosis (Figure $1 \mathrm{~A}-\mathrm{B}$ ).

At this point, an EBUS-type bronchoscopy was requested, performing cytology aspiration punctures by esophageal

Correspondence:

Silvia Calpena Martinez

Infectious Diseases Department, Fundación Jiménez Diaz, Universidad Autónoma de Madrid.

Av/ Reyes Católicos n², 28040, Madrid.

E-mail: silvia.calpena@quironsalud.es routes, and biopsies by means of mediastinoscopy. Given the disparity in the results, it was decided to access by thoracostomy, which pathological result demonstrated the existence of necrotizing granulomas.

With the pathological diagnosis of presumed disseminated tuberculosis (without microbiological confirmation) empirical treatment was started with isoniazid, rifampicin, pyrazinamide and ethambutol. Ten days after the start of treatment, he had fever and bulging, confluent and elevated papule-like lesions in the thoracic, dorsal, lumbar and abdominal regions (Figure $1 \mathrm{C}$ ). It was interpreted as an adverse drug reaction and anti-tuberculosis drugs was withdrawn. Two days after the pharmacological withdrawal, the skin lesions disappeared, so ethambutol and isoniazid were reintroduced and after five days pyrazinamide was added to the treatment. An hour later the rash reappeared on the face region, neck and trunk.

After the suspension of all the drugs the lesions practically disappeared, having only nausea and vomiting. The analysis highlighted hyperbilirubinemia of $4.1 \mathrm{mg} / \mathrm{dL}$ at the expense of direct, G0T 2,328 IU / L, GPT 1,939 IU / L, glycemia 52 mg / $\mathrm{dl}$ and INR 2.02 (prothrombin time $23 \mathrm{sec}$ ). He scored on the Meld scale 20 points [2].

Support therapy was administered, achieving progressive clinical and analytical improvement. Due to the favorable evolution, the treatment with ethambutol was reintroduced and he was followed up in outpatient consultations.

Finally, he continued home treatment and levofloxacin was added as the second tuberculostatic drug. Currently, the patient remains stable with double antituberculous therapy with a reevaluation thoracic-abdominal-pelvic scan (CT) which shows improvement in thoracic and abdominal lesions with decreased volume and size of lymphadenopathy.

The adverse effects of treatment are varied, although the most frequent are associated with digestive intolerance, liver toxicity and others of a mild nature such as anorexia or nausea [3]. Pyrazinamide, derived from nicotinamide, was introduced 

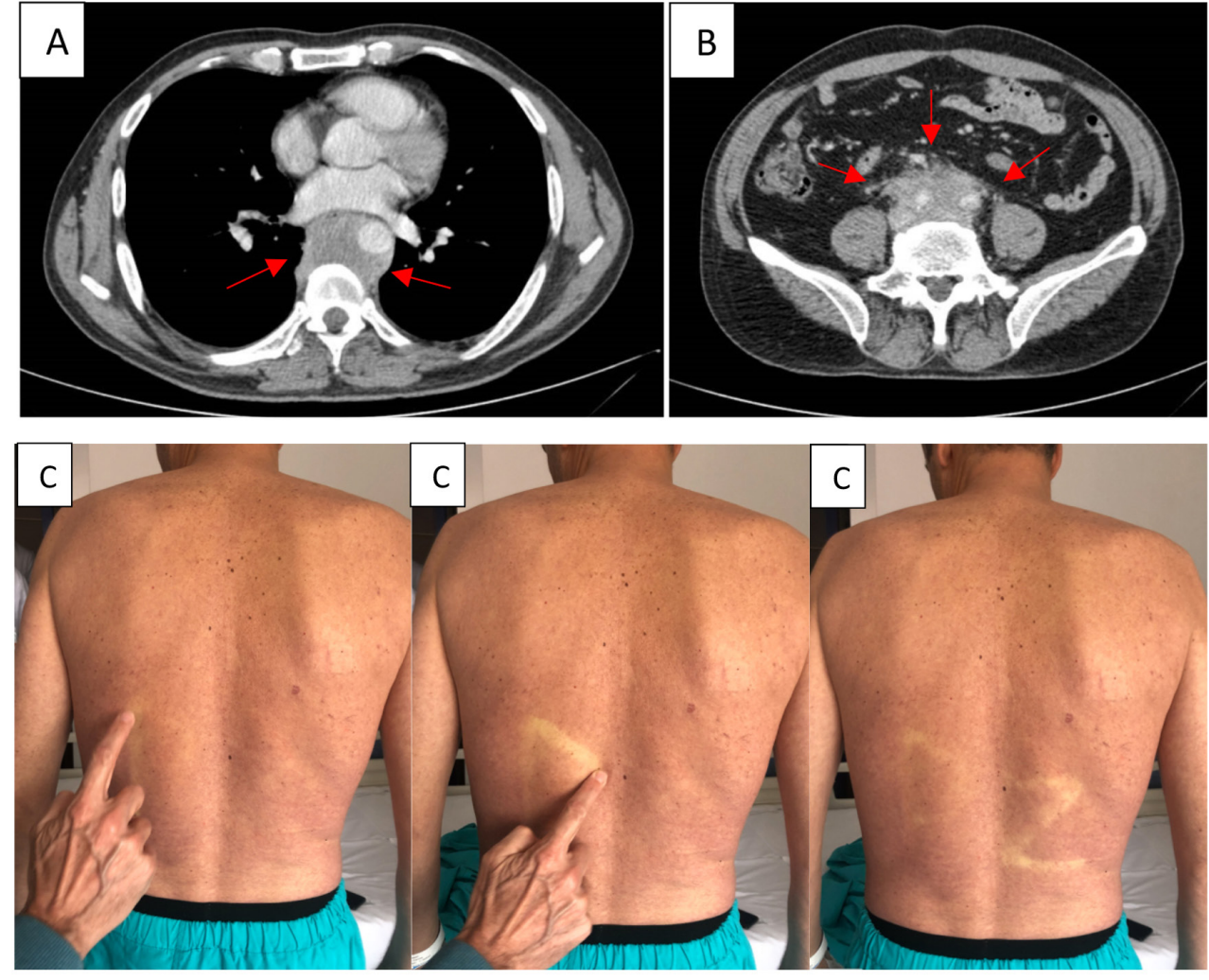

Figure 1 Thoraco CT: A soft tissue mass of thoracic location (A); Abdomen-pelvic CT: retroperitoneal fibrosis in the abdominal region (B); Extensive skin rash after taking pyrazinamide (C)

\begin{tabular}{|c|c|c|c|c|c|c|c|c|c|c|}
\hline Table 1 & $\begin{array}{l}\text { Sumr } \\
\text { pyraz }\end{array}$ & & & $\begin{array}{l}\text { acteristics in the bi } \\
\text { skin lesions. }\end{array}$ & iogra & ic referen & es of associ & tion betw & en treatm & t with \\
\hline Reference & Country & $\mathrm{N}$ & Age & Tuberculostatics & Fever & Rash & Appearance time & Withdrawal & Improvement & Reintroduction \\
\hline Ribi et al [4] & $\begin{array}{l}\text { Latin/ } \\
\text { American }\end{array}$ & 1 & 41 & $\begin{array}{l}\text { Isoniazid, Rifampicin, } \\
\text { Ethambutol, Pyrazinamide }\end{array}$ & No & Yes & 30 minutes & Yes & 24 hours & Progressive \\
\hline Perdu D et al [6] & France & 1 & 75 & $\begin{array}{l}\text { Isoniazid, Rifampicin, } \\
\text { Ethambutol, Pyrazinamide }\end{array}$ & No & $\begin{array}{l}\text { Yes, erythema } \\
\text { multiforme }\end{array}$ & 26 days & Yes & 5 days & Yes \\
\hline Olivier C et al [8] & France & 1 & 8 & $\begin{array}{l}\text { Isoniazid, Rifampicin, } \\
\text { Pyrazinamide, Ethambutol }\end{array}$ & Yes & Yes & 30 minutes & Yes & 1 hour & Yes \\
\hline \multirow[t]{3}{*}{ Radal M et al [9] } & France & 3 & 64 & $\begin{array}{l}\text { Rifampicin, Isoniazid, } \\
\text { Pyrazinamide }\end{array}$ & No & Yes & 30 minutes & Yes & $N A^{a}$ & Yes \\
\hline & & & 65 & $\begin{array}{l}\text { Rifampicin, Isoniazid, } \\
\text { Pyrazinamide }\end{array}$ & No & Yes & 1 hour & Yes & Hours & Progressive \\
\hline & & & 8 & $\begin{array}{c}\text { Isoniazid, Rifampicin, } \\
\text { Pyrazinamide, Ethambutol }\end{array}$ & Warm & Yes & 30 minutes & Yes & 1 hour & Partial \\
\hline
\end{tabular}




\begin{tabular}{|c|c|c|c|c|c|c|}
\hline \multirow{2}{*}{$\begin{array}{c}\text { Table } 1 \\
\\
\text { Reference }\end{array}$} & \multicolumn{6}{|c|}{$\begin{array}{l}\text { Summary of characteristics in the bibliographic references of association between } \\
\text { treatment with pyrazinamide and skin lesions. (continuation) }\end{array}$} \\
\hline & Sequence & Progressive doses & Rash appeareance & Features & Management & Pathologicalanatomy \\
\hline Ribi et al [4] & $\begin{array}{l}\text { 1st Isoniazid+ rifampicin } \\
\text { 2nd pyrazinamide }\end{array}$ & Yes. & Yes & Similar & $\begin{array}{l}\text { Pyrazinamide was replaced } \\
\text { by ciprofloxacin }\end{array}$ & No \\
\hline Perdu D et al [6] & Rifampicin + pyrazinamide & No & Yes & Similar & $\begin{array}{l}\text { Rifampicin was withdrawn } \\
\text { from treatment }\end{array}$ & Yes \\
\hline Olivier C et al [8] & $\begin{array}{l}\text { 1st Isoniazid+ rifampicin, } \\
\text { 2nd pyrazinamide }\end{array}$ & Yes, Pyrazinamide & Yes & Similar & $\begin{array}{l}\text { Lower dose treatment was } \\
\text { maintained }\end{array}$ & No \\
\hline \multirow[t]{3}{*}{ Radal M et al [9] } & $\begin{array}{l}\text { 1st Rifampicin, 2nd isoniazid, } \\
3^{0} \text { pyrazinamide }\end{array}$ & No & Yes & Similar & $\begin{array}{l}\text { Substitution of } \\
\text { pyrazinamide for } \\
\text { Ethambutol }\end{array}$ & No \\
\hline & $\begin{array}{l}\text { 1st Isoniazid+ rifampicin, } \\
\text { 2nd pyrazinamide }\end{array}$ & $\begin{array}{c}\text { Yes->Pyrazinamide } 1 / 3^{\mathrm{b}} \text { standard } \\
\text { dose } 2 / 3^{\mathrm{b}} \text { standard dose y } \\
\text { complete dose }\end{array}$ & No & $N A^{a}$ & $\begin{array}{l}\text { Standard dose treatment } \\
\text { was maintained }\end{array}$ & No \\
\hline & $\begin{array}{l}\text { 1st Isoniazid + rifampicin, } \\
\text { 2nd pyrazinamide }\end{array}$ & $\begin{array}{l}\text { Yes->Pyrazinamide } 1 / 3^{\mathrm{b}} \text { standard } \\
\text { dose y } 2 / 3^{\mathrm{b}} \text { standard dose }\end{array}$ & Yes & Similar & $\begin{array}{l}\text { Administration at lower } \\
\text { doses allowed maintaining } \\
\text { the treatment }\end{array}$ & No \\
\hline
\end{tabular}

${ }^{a}$ Not applicable (no information available). ${ }^{b}$ Reduced doses, expressed as fractions.

into the therapeutic arsenal of tuberculostatics in the 1950s. The most common adverse reaction is hepatitis, which occurs in 1-5\% of cases. Skin reactions have been described with a variable proportion from 1 to $13 \%[4,5]$.

Hypersensitivity reactions can occur with any of the tuberculostatic drugs, preferably manifesting as a pruritic, macular or papular erythematous rash that predominantly affects the trunk and proximal areas of the extremities. These effects usually appear in an interval of 3-7 weeks after the start of treatment [4], being more frequent and with severity criteria in HIV positive patients [6]. Other less prevalent but more serious entities have also been described such as Steven-Johnson syndrome, toxic epidermal necrolysis, generalized pustular rash, and DRESS (Drug Rash with Eosinophilia and Systemic Symptons) syndrome [7]. However, it should be noted that the existence of a hypersensitivity reaction does not exclude that the patient may develop an anaphylactic reaction [3].

It is necessary to identify the drugs responsible for hypersensitivity reactions, for which the sequential introduction with each of the compounds at reduced doses should be carried out. In patients who initially had a severe hypersensitivity reaction, the use of much smaller doses should be prioritized [3].

There are not many reported cases of acute skin toxicity from pyrazinamide (Table 1). However, all of them show a clinical picture similar to our case, with the appearance of a sudden acute skin rash after ingestion of the drug. That is why it is important to promptly identify and withdraw the medication.

\section{FUNDING}

None to declare.

\section{CONFLICTS OF INTEREST}

The authors declare no conflicts of interest.

\section{REFERENCES}

1. González-Martín J, García-García JM, Anibarro L, Vidal R, Esteban J, Blanquer R, Moreno S, Ruiz-Manzano J. Documento de consenso sobre diagnóstico, tratamiento y prevención de la tuberculosis [Consensus document on the diagnosis, treatment and prevention of tuberculosis]. Arch Bronconeumol. 2010; 46(5):255-74. doi: 10.1016/j.arbres.2010.02.010.

2. Yantorno SE, Kremers WK, Ruf AE, Trentadue JJ, Podestá LG, Villamil FG. MELD is superior to King's college and Clichy's criteria to assess prognosis in fulminant hepatic failure. Liver Transpl. 2007; 13(6):822-8. doi: 10.1002/lt.21104.

3. Patel AM, McKeon J. Avoidance and management of adverse reactions to antituberculosis drugs. Drug Saf. 1995; 12(1):1-25. doi: 10.2165/00002018-199512010-00001.

4. Ribi $C$, Hauser C. Adverse reactions to pyrazinamide. Allergy. 2002;57(10):964-5. doi: 10.1034/j.1398-9995.2002.23832_9.x.

5. Kuaban C, Bercion R, Koula-Shiro S. Current HIV seroprevalence rate and incidence of adverse skin reactions in adults with pulmonary tuberculosis receiving thiacetazone-free antituberculosis treatment in Yaounde, Cameroon. Cent Afr J Med. 1998;44(2):34-7. PMID: 9675969.

6. Perdu D, Lavaud F, Prévost A, Deschamps F, Cambie MP, Bongrain $E_{1}$ Barhoum K, Kalis B. Erythema multiforme due to pyrazinamide. Allergy. 1996;51(5):340-2. doi: 10.1111/j.1398-9995.1996.tb04620.x.

7. Stern RS. Clinical practice. Exanthematous drug eruptions. N Engl J Med. 2012; 366(26):2492-501. doi: 10.1056/NEJMcp1 104080. 
8. Olivier C, Radal M, Mazaud S, Jonville-Béra AP, Martel C, Autret E. Eruption après une première prise d'une quadrithérapie antituberculeuse: penser au pyrazinamide [Skin eruption after the first dose of antitubercular quadri-therapy: consideration of pyrazinamide]. Arch Pediatr. 1998; 5(3):289-90. doi: 10.1016/s0929693x(97)89371-2.

9. Radal M, Jonville-Bera AP, Van-Egroo C, Carré P, Lemarié E, Autret E. Eruption après la première prise d'une chimiothérapie standard antituberculeuse. Penser au pyrazinamide [Eruption after the 1st dose of standard antitubercular chemotherapy. Thoughts on pyrazinamide]. Rev Mal Respir. 1998; 15(3):305-6. PMID: 9677642. 